Review Article

\title{
Zinc, Copper, and Iron in Oral Submucous Fibrosis: A Meta-Analysis
}

\author{
Prageet K. Sachdev $\mathbb{D}^{1},{ }^{1}$ Jeanne Freeland-Graves $\left(\mathbb{D},{ }^{1}\right.$ S. Natasha Beretvas $\left(\mathbb{D},{ }^{2}\right.$ \\ and Namrata Sanjeevi $\mathbb{D}^{1}$ \\ ${ }^{1}$ Department of Nutritional Sciences, College of Natural Sciences, The University of Texas at Austin, 103 W. 24th St. A2703, \\ Austin, TX 78712, USA \\ ${ }^{2}$ Department of Educational Psychology, The University of Texas at Austin, George I. Sánchez Building 538E, 1912 Speedway, \\ Austin, TX 78712, USA
}

Correspondence should be addressed to Jeanne Freeland-Graves; jfg@mail.utexas.edu

Received 19 December 2017; Revised 22 April 2018; Accepted 6 May 2018; Published 26 June 2018

Academic Editor: Spiros Zinelis

Copyright (c) 2018 Prageet K. Sachdev et al. This is an open access article distributed under the Creative Commons Attribution License, which permits unrestricted use, distribution, and reproduction in any medium, provided the original work is properly cited.

\begin{abstract}
Oral submucous fibrosis (OSF) is a potentially malignant disorder which causes fibrosis and inflammation of the oral mucosa. Studies have reported altered levels of trace elements in oral submucous fibrosis subjects, but findings have been inconsistent. The objective of this research is to perform a meta-analysis to summarize studies that report zinc $(\mathrm{Zn})$, copper $(\mathrm{Cu})$, and iron $(\mathrm{Fe})$ in patients, with and without OSF. A literature search of Embase, PubMed, Cochrane Library, and Web of Science electronic databases was conducted for studies up to January 2017. A total of 34 reports met the inclusion criteria. The standardized mean difference was utilized as the effect size. The robust variance estimation method was chosen to handle dependency of multiple related outcomes in meta-analysis. There was a significant increase in the levels of $\mathrm{Cu}$ (effect size $=1.17, p$ value $<0.05,95 \%$ confidence interval (CI): 0.164-2.171) and a significant decrease in levels of $\mathrm{Zn}$ (effect size $=-1.95$, $p$ value $<0.05$, 95\% CI: -3.524 to -0.367 ) and $\mathrm{Fe}$ (effect size $=-2.77, p$ value $<0.01,95 \% \mathrm{CI}:-4.126$ to -1.406 ) in OSF patients. The estimation of $\mathrm{Zn}, \mathrm{Cu}$, and $\mathrm{Fe}$ levels may serve as additional biomarkers in the diagnosis and prognosis of OSF along with the clinical features.
\end{abstract}

\section{Introduction}

Oral submucous fibrosis (OSF) is a potentially malignant disorder (WHO, 2017) that causes fibrosis and inflammation of the oral mucosa [1]. This condition is more prevalent in South and Southeast Asia, particularly India, with fewer cases reported in Europe and North America [2-4]. The prevalence of OSF cases has increased from $0.03 \%$ to $6.42 \%$ in the last four decades, making it a significant public health problem in India [3]. This disease contributes significantly to mortality because of its high malignant transformation rate of $7.6 \%[4,5]$. The disease is more prevalent in men, perhaps due to taboos associated with oral chewing habits in women [4]. Several studies have provided evidence that chewing of areca nut is the primary etiological factor for the development of OSF [6-9]. In a case-control study, it was found that
98\% of the patients with OSF chewed areca nut regularly, compared to $38 \%$ among the healthy controls [7]. Maher et al. observed an increased risk of development of OSF in those who chewed areca nut (relative risk $=154$ ) [8].

The areca nut grows on the areca catechu palm tree which is commonly found in Pacific Islands and South Asia [10]. It is consumed wrapped in betel leaves or in form of commercial preparation of pan masala, mawa, gutkha (a preparation of betel nuts and tobacco designed to be chewed), or supari [10]. The areca nut is composed of alkaloid components [10]. The most potent alkaloid, arecoline, causes an abnormal increase in the production of collagen by the oral mucosal fibroblasts. This over production leads to the development of fibrotic bands in the buccal mucosa of OSF patients [11]. The condition begins as an inflammatory response to areca nut chewing, followed by fibrosis of the 
oral submucosa and then progresses to induce restriction of the mouth opening and difficulty in mastication and swallowing [10]. The early stage symptoms include burning sensation in the mouth, development of ulcers and vesicles, increased salivation, and blanching of the mucosa. In the later stages, the mucosa becomes inelastic and leathery because of the fibrotic bands [7, 10].

Altered trace element status has been reported in both the potentially malignant and malignant stages [12-14]. Microminerals are well established to be essential in metabolism as components of enzymes and hormones in the body. This research will focus on three trace minerals $-\mathrm{Zn}$, $\mathrm{Cu}$, and $\mathrm{Fe}$ - that are altered in OSF. Zinc is crucial for the normal functioning of the immune cells [15], antioxidant defense, wound healing, and stability of biological membranes [15]. Chewing of areca nut generates reactive oxygen species, which can cause damage to the proteins and nucleic acids in the body. $\mathrm{Zn}$ induces activation of antioxidant enzyme superoxide dismutase (SOD) which inhibits production of reactive oxygen species [15]. The levels of SOD were found to be reduced $(75.42 \pm 7.04)$ in OSF patients as compared to controls $(177.17 \pm 5.92)$ [16]. The mineral copper plays an important role in the formation of red blood cells and synthesis of collagen in the bones and connective tissue and aids in the absorption of iron [17]. It is also essential for the functioning of enzymes such as $\mathrm{Cu} / \mathrm{Zn}$ superoxide dismutase and lysyl oxidase [18]. Related to OSF, $\mathrm{Cu}$ is a cofactor for lysyl oxidase, the enzyme involved in the maturation of collagen [19]. The areca nut contains a high content of $\mathrm{Cu}$ that is released within 5-30 minutes of chewing the nut, inducing upregulation of lysyl oxidase in the oral mucosa $[20,21]$. Trivedy et al. observed that the levels of $\mathrm{Cu}$ in the saliva peaked after $10 \mathrm{mins}$ in two volunteers and 20 minutes in the third volunteer after chewing an areca nut product for 30 minutes [20]. It has been suggested that the elevated levels may then induce excessive collagen formation by the fibroblasts [21]. Iron is required for the functioning of numerous enzymes such as cytochrome oxidase, xanthine oxidases, succinate dehydrogenase, glucose6-phosphate dehydrogenase, catalases, peroxidases, and choline dehydrogenase [22]. It acts as a cofactor for prolyl hydroxylase $(\mathrm{PH})$ and lysyl hydroxylase, which are enzymes involved in hydroxylation of collagen [22]. Excessive collagen synthesis in OSF may result in a decline in the levels of serum and plasma Fe in OSF patients. Finally, the burning sensation and the restricted mouth opening in this disease limits the intake of food, further exacerbating deficiencies of micronutrients $[23,24]$. The Fe dependent enzyme, cytochrome oxidase, is required for the development of the epithelium [25]. A deficiency of iron in OSF reduces the levels of cytochrome oxidase, resulting in atrophy of the epithelium [25]. Investigations have reported diminished $\mathrm{Zn}$ and $\mathrm{Fe}$ values in OSF subjects, as compared to healthy controls [26-31]. In contrast, $\mathrm{Cu}$ levels in serum/plasma/saliva have been observed to be elevated rather consistently [23, 26, 28-30, 32-38].

Although studies have attempted to explore the status of trace elements in OSF patients, results to date have been inconclusive. Differences exist in sample age, gender, biological samples (serum, plasma, and saliva), and laboratory methods used by the investigators. In addition, all these studies have measured multiple micronutrients (outcomes), which may have synergistic and antagonistic interactions. Thus, multiple outcomes reported by each study cannot be considered independent of each other. In order to adjust for these interactions in calculation of the pooled effect sizes for each micronutrient, information on correlations is needed from each study. However, the primary studies did not report correlations between the trace elements. Consequently, this research will use a sophisticated statistical technique of robust variance estimation to (a) summarize the existing literature and conduct a meta-analysis to evaluate differences in $\mathrm{Zn}, \mathrm{Cu}$, and $\mathrm{Fe}$ status between OSF and healthy participants and (b) identify the influence of moderators (male sex and biological samples (plasma, serum, or saliva)). The robust variance estimation is a fairly new and powerful approach to handle dependency between multiple nonindependent outcomes when the information on within-study covariance is not available [39]. In addition, this research also will calculate ratios of $\mathrm{Zn} / \mathrm{Cu}$ and $\mathrm{Cu} / \mathrm{Fe}$ from the primary studies; these will be used further to generate a weight average or pooled difference in these ratios between OSF and healthy participants.

\section{Methods and Materials}

2.1. Data Sources and Search Strategy. A comprehensive literature search was conducted to identify relevant prospective, case-controlled, and cross-sectional studies investigating the status of $\mathrm{Zn}, \mathrm{Cu}$, and $\mathrm{Fe}$ in OSF from 1980 to January 2017. The electronic databases of PubMed, Embase, Web of Science, and Cochrane Library were searched as detailed in Figure 1. The reference list of selected articles and reviews on the topic also were searched. A total of 323 studies were extracted, using the keywords oral submucous fibrosis, oral potentially malignant lesion and trace elements, micronutrients, zinc, copper, iron, $\mathrm{Zn}, \mathrm{Cu}$, and $\mathrm{Fe}$. Seven studies were excluded because of nonavailability of full-text articles or nonhuman research articles. The 42 articles finally retrieved were then subject to the exclusion criteria, resulting in a total of 34 studies that were used for the final analysis.

2.2. Inclusion and Exclusion Criteria. All potentially relevant publications were reviewed independently by two reviewers using the inclusion criteria. Inclusion criteria were prospective, cross-sectional, or case-control investigations and studies measuring concentrations of trace elements in both healthy controls and OSF participants.

Exclusion criteria were studies with inadequate information, such as sample size and standard deviation for the calculation of the effect sizes, absence of the control group, measurement of tissue levels of the micronutrients, and nonhuman research. Duplicate experiments were removed, and any disagreement regarding inclusion was resolved with the aid of a third reviewer. Five studies that did not report sample size and standard deviation were excluded [40-44]. Also, two studies that measured only tissue levels of 


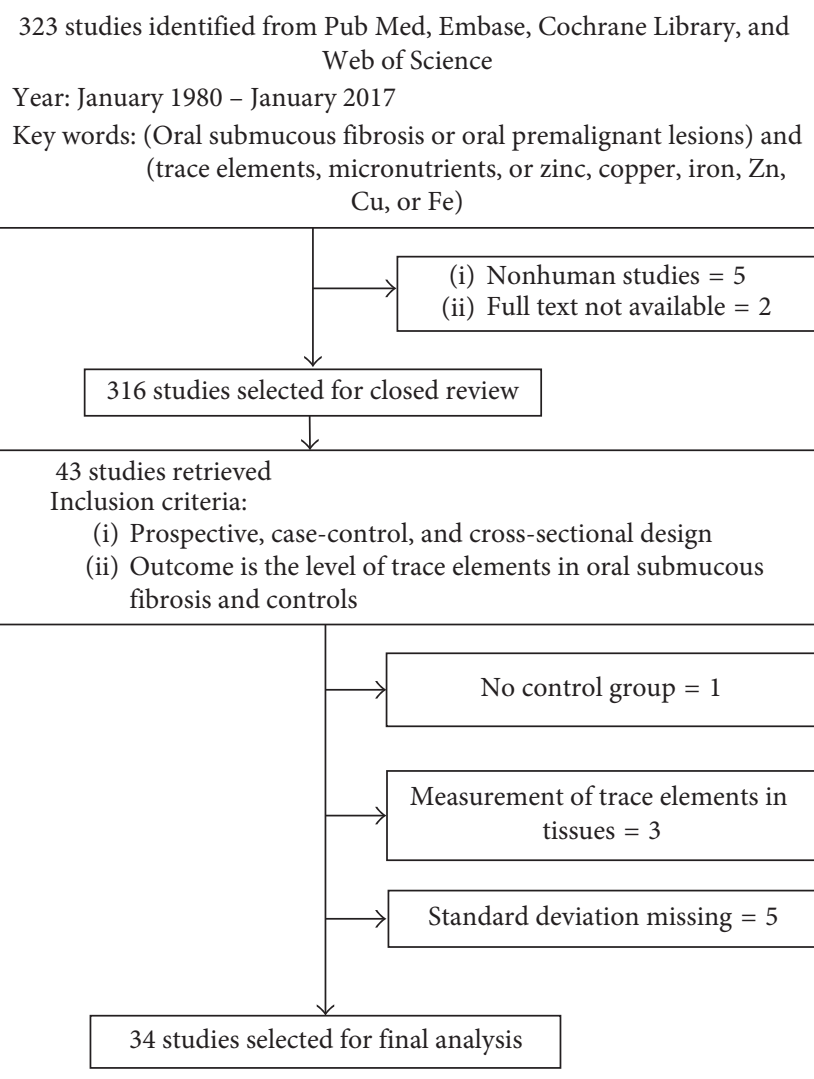

FIGURE 1: Flowchart illustrating the process of study selection for the meta-analysis.

micronutrients [45-47] and one study that did not have a control group were excluded [46].

2.3. Data Extraction. Mean values and standard deviations of plasma, serum, and salivary $\mathrm{Zn}, \mathrm{Cu}$, and $\mathrm{Fe}$ in control and OSF groups were extracted from the included studies. Author, the year of publication, sample size, and age of participants also were recorded. In addition, the type of biomarker (serum/plasma/saliva) and proportion of males among the OSF participants were collected to conduct moderator analysis. This meta-analysis included 34 studies, with total of 2409 participants.

2.4. Statistical Analyses. All data were analyzed in the Statistical Package for Social Sciences (SPSS Version 22, Armonk, NY, 2013) [48]. Characteristics of the publications that were included are presented in Table 1 [12, 23, 24, 26-38, 49-66]. Standard deviations of the micronutrient values and their associated sample sizes were used to calculate the pooled sample variances. The standardized mean differences, Hedges $g$ [67], were calculated by subtracting the means of the trace element values in the healthy controls from the means of OSF patients and then dividing the difference by the pooled standard deviation. The above procedure was performed to handle the different units of measurement used. Small-sample bias correction was applied to obtain the bias-corrected
Hedges $g$. The variance and 95\% confidence interval estimate of the effect size estimates were determined.

The negative effect sizes represented lower levels of the trace elements in the OSF participants, as compared to the healthy controls. More than one effect size was extracted from each report to explore interactions among the minerals in the disease.

Studies included in a meta-analysis usually contain information on only one outcome. The present report differs in that each investigation provides levels of three trace elements, $\mathrm{Zn}, \mathrm{Cu}$, and Fe (three outcomes) from the same individuals; this results in effect sizes that are correlated. Two possible approaches to handle the multiple outcome data are (1) to incorporate correlations between the micronutrients as reported by the original studies in the analysis or (2) discard effect sizes such that each study contributes only one effect size but with the downside of losing information on some of the micronutrients [39]. The original studies on OSF did not provide correlations between these three trace elements. In addition, previous investigations have observed that increased $\mathrm{Cu}$ is associated with a reduction in $\mathrm{Zn}$, thereby implying that these effect sizes are not independent of each other [23, 29]. When the dependence between multiple outcomes is not taken into consideration, the assumed correlation is 0 , which implies that the outcomes are unrelated. This results in an underestimation of variance of the overall effect size. In contrast, a correlation of 1 creates an overestimation of the variance for the composite effect size. Both these scenarios can inflate Type I and Type II errors, respectively [68]. In this research, the pooled average effect size and variance were calculated using the robust variance estimation method, by applying Tipton's [69] small-sample bias correction in the statistical software $\mathrm{R}$ (3.4.0). The robust variance estimation (RVE) is a sophisticated metaanalytical technique that handles dependency between outcomes, while controlling for Type I and Type II errors [39]. It does not require the information on the withinstudy covariance of the original studies and is not based on the assumption of normality of the effect sizes $[39,68]$. The output included the pooled average effect size, the standard deviation, the Z-statistic, and $95 \%$ confidence intervals. The effects of the moderators on the effect size were analyzed using the mixed effects meta-regression model. All the results were tested using an alpha level of 0.05 to discern statistical significance. Forest plots were created to graphically represent the results of the meta-analysis. All the equations and formulas used in the analysis were derived from The Handbook of Research Synthesis and MetaAnalysis [68].

The ratios of $\mathrm{Zn} / \mathrm{Cu}$ and $\mathrm{Cu} / \mathrm{Fe}$ also were calculated from all studies (Tables 2 and 3 resp.). All studies had different sample sizes, so a weighted average or pooled estimate of the difference in ratios of levels of trace elements between OSF and controls was calculated. This provided more weight to studies that had a larger sample size. Thus, the weighted average of the differences between $\mathrm{Zn} / \mathrm{Cu}$ ratios in OSF and healthy controls was determined. Similarly, the weighted average of difference between $\mathrm{Cu} / \mathrm{Fe}$ ratios in OSF and 
TABLE 1: Characteristics and moderators of studies included in the meta-analysis investigating differences in levels of zinc, copper, and iron between healthy controls and subjects with oral submucous fibrosis.

\begin{tabular}{|c|c|c|c|c|c|c|c|c|}
\hline \multirow{2}{*}{ Author, year (reference) } & \multirow{2}{*}{ Biomarker } & \multirow{2}{*}{ Age } & \multirow{2}{*}{ Men (\%) } & \multicolumn{2}{|c|}{ Sample size $(n)$} & \multicolumn{3}{|c|}{ Effect size } \\
\hline & & & & Patient & Control & Zinc & Copper & Iron \\
\hline Gupta et al., 1987 [12] & Serum & 35 & 65 & 40 & 10 & 0.112 & 1.264 & $-{ }^{b}$ \\
\hline Varghese et al., 1987 [50] & Serum & 38.85 & 16 & 50 & 50 & -3.800 & -6.541 & $-{ }^{b}$ \\
\hline Rajendran et al., 1992 [49] & Serum & $-^{\mathrm{a}}$ & $-{ }^{a}$ & 50 & 50 & $-{ }^{b}$ & $-^{\mathrm{b}}$ & -30.170 \\
\hline Anuradha and Devi, 1995 [27] & Plasma & $-{ }^{\mathrm{a}}$ & $-^{\mathrm{a}}$ & 22 & 22 & -5.436 & -5.730 & -8.461 \\
\hline Luqumun et al., 2003 [50] & Serum & $17-40$ & 67 & 15 & 15 & $-{ }^{\mathrm{b}}$ & 1.846 & -0.349 \\
\hline Pillai and Burde, 2005 [32] & Serum & 23.40 & $-^{\mathrm{a}}$ & 40 & 31 & $-{ }^{\mathrm{b}}$ & -0.427 & $-{ }^{b}$ \\
\hline Khanna and Karjodkar, 2006 [52] & Serum & $25-70$ & 83 & 30 & 30 & $-{ }^{\mathrm{b}}$ & 0.862 & -3.156 \\
\hline Nayak et al., $2010[65]$ & Serum & $22-60$ & 95 & 20 & 20 & -0.345 & -0.404 & $-^{\mathrm{b}}$ \\
\hline Balpande and Sathawane, 2010 [23] & Serum & $-^{\mathrm{a}}$ & $-^{\mathrm{a}}$ & 30 & 30 & -2.386 & 4.572 & -8.975 \\
\hline Shettar, $2010[31]$ & Serum & 29.60 & 80 & 30 & 30 & -1.806 & 0.975 & $-^{\mathrm{b}}$ \\
\hline Tadakamadla et al., 2011 [33] & Serum & $18-70$ & 90 & 50 & 50 & $-^{\mathrm{b}}$ & 1.145 & -0.579 \\
\hline Ayinamudi and Narsimhan, 2012 [63] & Serum & $23-62$ & 67 & 15 & 6 & 0.959 & 1.683 & $-\mathrm{b}$ \\
\hline Shetty et al., 2012 [53] & Serum & ${ }^{\mathrm{a}}$ & $-{ }^{a}$ & 65 & 21 & $-\mathrm{b}$ & $-\mathrm{b}$ & -0.452 \\
\hline Shetty et al., 2012 [53] & Saliva & $-{ }^{\mathrm{a}}$ & $-^{\mathrm{a}}$ & 65 & 21 & $-{ }^{\mathrm{b}}$ & $-{ }^{\mathrm{b}}$ & -0.399 \\
\hline Hegde et al., 2012 [66] & Serum & 26.85 & 85 & 15 & 60 & $-{ }^{\mathrm{b}}$ & $-{ }^{\mathrm{b}}$ & -3.501 \\
\hline Neethi et al., 2013 [55] & Serum & 36.53 & 73 & 30 & 30 & -0.521 & 0.758 & $-\mathrm{b}$ \\
\hline Khanna et al., 2013 [34] & Serum & 36.85 & $-{ }^{\mathrm{a}}$ & 30 & 30 & 0.216 & 0.809 & $-{ }^{b}$ \\
\hline Kode and Karjodkar, 2013 [28] & Serum & $-^{\mathrm{a}}$ & $-^{\mathrm{a}}$ & 30 & 15 & 1.424 & 0.205 & -0.642 \\
\hline Kode and Karjodkar, 2013 [28] & Saliva & $-^{\mathrm{a}}$ & $-^{\mathrm{a}}$ & 30 & 15 & 0.497 & 0.512 & -0.517 \\
\hline Kapoora et al., 2013 [24] & Serum & $15-55$ & 84 & 50 & 50 & -17.943 & 83.349 & -37.786 \\
\hline Shetty et al., 2013 [54] & Serum & $-^{\mathrm{a}}$ & 94 & 50 & 50 & -4.932 & $-^{\mathrm{b}}$ & -9.023 \\
\hline Hosthor et al., 2014 [29] & Serum & $-^{\mathrm{a}}$ & $-^{\mathrm{a}}$ & 30 & 30 & -4.612 & 6.336 & -4.729 \\
\hline Gurprasad et al., 2014 [56] & Serum & 32.5 & 90 & 50 & 35 & $-{ }^{\mathrm{b}}$ & $-{ }^{\mathrm{b}}$ & -2.853 \\
\hline Shetty et al., $2015[30]$ & Saliva & $-{ }^{\mathrm{a}}$ & $-^{\mathrm{a}}$ & 50 & 50 & -2.485 & 10.989 & -14.582 \\
\hline Yadav et al., 2015 [35] & Saliva & 28.6 & 84 & 50 & 50 & -1.112 & 1.644 & $-{ }^{b}$ \\
\hline Okade et al., 2015 [36] & Saliva & 24.3 & 97 & 30 & 30 & $-{ }^{\mathrm{b}}$ & 0.291 & -1.862 \\
\hline Hafeez et al., 2015 [57] & Serum & 49 & 88.8 & 89 & 89 & $-{ }^{\mathrm{b}}$ & $-^{\mathrm{b}}$ & -0.601 \\
\hline Saurabh et al., 2015 [58] & Serum & $18-45$ & 83.3 & 30 & 30 & $-{ }^{\mathrm{b}}$ & $-{ }^{\mathrm{b}}$ & -3.901 \\
\hline Srilekha, 2015 [37] & Serum & $30-50$ & 60 & 22 & 22 & -0.223 & 2.545 & $-{ }^{\mathrm{b}}$ \\
\hline Mohammed et al., 2016 [61] & Saliva & 32.73 & 90 & 30 & 30 & $-\mathrm{b}$ & 1.772 & $-^{\mathrm{b}}$ \\
\hline Kallalli et al., 2016 [59] & Serum & $20-60$ & 78 & 30 & 10 & $-{ }^{\mathrm{b}}$ & $-^{\mathrm{b}}$ & -7.002 \\
\hline Tiwari et al., 2016 [38] & Serum & 41.1 & 75 & 40 & 30 & $-{ }^{\mathrm{b}}$ & 2.349 & -2.074 \\
\hline More and Patel, 2016 [26] & Serum & 32.43 & 73 & 30 & 30 & -10.576 & 3.015 & $-\mathrm{b}$ \\
\hline Kumar et al., 2016 [64] & Serum & 42.6 & 89 & 35 & 35 & $-{ }^{\mathrm{b}}$ & 0.927 & -0.508 \\
\hline Bhardwaj et al., 2016 [62] & Serum & $16-65$ & 83 & 40 & 40 & $-{ }^{\mathrm{b}}$ & $-{ }^{\mathrm{b}}$ & -2.085 \\
\hline Thakur and Guttikonda, 2017 [60] & Serum & ${ }^{\mathrm{a}}$ & $-{ }^{\mathrm{a}}$ & 40 & 40 & $-^{\mathrm{b}}$ & $-^{\mathrm{b}}$ & -1.966 \\
\hline
\end{tabular}

${ }^{a}$ Not reported in the primary study. ${ }^{b}$ Not measured in the primary study.

healthy controls also was determined via the following formula:

$$
\begin{aligned}
& {[(n 1 * \text { difference in } \mathrm{Zn} / \mathrm{Cu}(\mathrm{OSF}-\text { controls }))} \\
& \quad+(n 2 * \text { difference in } \mathrm{Zn} / \mathrm{Cu}(\mathrm{OSF}-\text { controls })) \\
& +(n 3 * \text { difference in } \mathrm{Zn} / \mathrm{Cu}(\mathrm{OSF}-\text { controls })) \\
& +(n * \text { last difference in } \mathrm{Zn} / \mathrm{Cu}(\mathrm{OSF}-\text { controls }))] \\
& \quad \cdot(n 1+n 2+\cdots+n(\text { last study }))
\end{aligned}
$$

where $n$ is the total sample size of a study.

\section{Results}

Figure 1 illustrates the steps of the screening process involved in the selection of articles for the meta-analysis. The numbers of effect sizes for $\mathrm{Zn}, \mathrm{Cu}$, and Fe were 17, 24, and 23 , respectively, for a total of 64 effect sizes. There was a significant increase in the levels of $\mathrm{Cu}$ (effect size $=1.17$, $p$ value $<0.05,95 \%$ confidence interval (CI): 0.164-2.171) and a significant decrease in levels of $\mathrm{Zn}$ (effect size $=-1.95$, $p$ value $<0.05,95 \% \mathrm{CI}:-3.524$ to -0.367 ) and Fe (effect size $=-2.77 p$ value $<0.01,95 \%(\mathrm{CI}):-4.126$ to -1.406$)$ in OSF patients, as compared to controls. However, the high $\mathrm{I}^{2}$ value of $97.24 \%$ indicates a high level of heterogeneity between the studies included.

The pooled differences in $\mathrm{Zn} / \mathrm{Cu}$ ratio and $\mathrm{Cu} / \mathrm{Fe}$ ratios between OSF and healthy participants were -0.3046 and 0.9826 .

3.1. Forest Plots. The results on levels of $\mathrm{Zn}$ and Fe in OSF versus healthy participants in this meta-analysis are supported further by the forest plots in Figures 2-4. The majority of the first studies $(n=10)$ in the forest plot for $\mathrm{Zn}$ show lower zinc levels in OSF subjects as compared to healthy participants. The results from five studies were not 
TABLE 2: $\mathrm{Zn} / \mathrm{Cu}$ ratios calculated from different studies.

\begin{tabular}{|c|c|c|c|c|c|}
\hline Reference & Biomarker & Controls & OSMF & $\begin{array}{c}\text { Total } \\
\text { sample }\end{array}$ & $\begin{array}{l}\text { Difference } \\
\text { in } \mathrm{Zn} / \mathrm{Cu} \\
\text { (OSMF- } \\
\text { control) }\end{array}$ \\
\hline $\begin{array}{l}\text { Gupta et al. } \\
{[12]}\end{array}$ & Serum & 0.87 & 0.72 & 50 & -0.15 \\
\hline $\begin{array}{l}\text { Varghese } \\
\text { et al. [50] }\end{array}$ & Serum & 0.92 & 0.85 & 100 & -0.07 \\
\hline $\begin{array}{l}\text { Nayak et al. } \\
{[65]}\end{array}$ & Serum & 0.88 & 0.92 & 40 & 0.04 \\
\hline $\begin{array}{l}\text { Balpande } \\
\text { and } \\
\text { Sathawane } \\
{[23]}\end{array}$ & Serum & 1.72 & 1.09 & 60 & -0.63 \\
\hline $\begin{array}{l}\text { Ayinamudi } \\
\text { and } \\
\text { Narsimhan } \\
{[63]}\end{array}$ & Serum & 0.05 & 0.04 & 21 & -0.01 \\
\hline Shettar [31] & Serum & 0.96 & 0.76 & 60 & -0.2 \\
\hline $\begin{array}{l}\text { Neethi et al. } \\
\text { [55] }\end{array}$ & Serum & 0.73 & 0.7 & 60 & -0.03 \\
\hline $\begin{array}{l}\text { Khanna } \\
\text { et al. } \\
{[34]}\end{array}$ & Serum & 1.47 & 1.32 & 60 & -0.15 \\
\hline $\begin{array}{l}\text { Kode and } \\
\text { Karjodkar } \\
{[28]}\end{array}$ & Serum & 1.48 & 2.05 & 45 & 0.57 \\
\hline $\begin{array}{l}\text { Kode and } \\
\text { Karjodkar } \\
{[28]}\end{array}$ & Saliva & 13.23 & 14.7 & 45 & 1.47 \\
\hline $\begin{array}{l}\text { Hosthor } \\
\text { et al. [29] }\end{array}$ & Serum & 0.77 & 0.19 & 60 & -0.58 \\
\hline $\begin{array}{l}\text { Shetty et al. } \\
{[30]}\end{array}$ & Saliva & 0.78 & 0.28 & 100 & -0.5 \\
\hline $\begin{array}{l}\text { Yadav et al. } \\
\text { [35] }\end{array}$ & Saliva & 1.19 & 0.47 & 100 & -0.72 \\
\hline $\begin{array}{l}\text { More and } \\
\text { Patel [26] }\end{array}$ & Serum & 2.92 & 0.86 & 60 & -2.06 \\
\hline
\end{tabular}

statistically significant $[4,12,28,34,37]$ since the confidence intervals crossed the line of null effect (standard mean difference $=0$ ). Two studies showed high $\mathrm{Zn}$ levels in OSF patients $[28,63]$.

In the forest plot for $\mathrm{Cu}$ (Figure 3 ), the majority of the studies $(n=18)$ illustrate the higher levels of $\mathrm{Cu}$ in OSF patients as compared to controls. Two studies [27, 50] showed exceptionally low levels of copper. Yet, the results of five studies were not statistically significant $[4,28,32,36]$ since the confidence interval crossed the line of null effect.

Finally, in the forest plot for iron, majority of the studies $(n=21)$ showed lower levels of $\mathrm{Fe}$ in OSF patients as compared to that of healthy controls. However, one study documented higher Fe levels in OSF patients [61] as compared to the controls.

It should be noted that the two studies that had large effect sizes and suggested outliers were removed from the analysis $[24,49]$. The horizontal axis (x-axis) of forest plots represents the standardized mean differences. The vertical line in the plot indicates "line of null effect" or no statistically significant difference in levels of trace elements between the
TABLE 3: $\mathrm{Cu} / \mathrm{Fe}$ ratios calculated from studies included.

\begin{tabular}{|c|c|c|c|c|c|}
\hline Reference & Biomarker & Controls & OSMF & $\begin{array}{c}\text { Total } \\
\text { sample }\end{array}$ & $\begin{array}{c}\text { Difference } \\
\text { in } \mathrm{Zn} / \mathrm{Cu} \\
\text { (OSMF- } \\
\text { control) }\end{array}$ \\
\hline $\begin{array}{l}\text { Anuradha } \\
\text { and Devi } \\
\text { [27] }\end{array}$ & Plasma & 1.2 & 2 & 44 & 0.8 \\
\hline $\begin{array}{l}\text { Luqumun } \\
\text { et al. [51] }\end{array}$ & Serum & 1.06 & 1.37 & 30 & 0.31 \\
\hline $\begin{array}{l}\text { Khanna and } \\
\text { Karjodkar } \\
{[52]}\end{array}$ & Serum & 1.11 & 1.26 & 60 & 0.15 \\
\hline $\begin{array}{l}\text { Balpande } \\
\text { and } \\
\text { Sathawane } \\
{[23]}\end{array}$ & Serum & 1.22 & 2.09 & 60 & 0.87 \\
\hline $\begin{array}{l}\text { Tadakmadla } \\
\text { et al. [33] } \\
\text { Kode and }\end{array}$ & Serum & 0.88 & 1.16 & 100 & 0.28 \\
\hline $\begin{array}{l}\text { Karjodkar } \\
\text { [28] }\end{array}$ & Serum & 0.99 & 1.36 & 45 & 0.37 \\
\hline $\begin{array}{l}\text { Kode and } \\
\text { Karjodkar } \\
{[28]}\end{array}$ & Saliva & 0.11 & 0.33 & 45 & 0.22 \\
\hline $\begin{array}{l}\text { Hosthor } \\
\text { et al. [29] }\end{array}$ & Serum & 1.06 & 5.25 & 60 & 4.19 \\
\hline $\begin{array}{l}\text { Shetty et al. } \\
{[30]}\end{array}$ & Saliva & 0.61 & 2.45 & 100 & 1.84 \\
\hline $\begin{array}{l}\text { Okade et al. } \\
{[36]}\end{array}$ & Saliva & 0.1 & 1.75 & 60 & 1.65 \\
\hline $\begin{array}{l}\text { Tiwari et al. } \\
\text { [38] }\end{array}$ & Serum & 0.99 & 1.25 & 70 & 0.26 \\
\hline $\begin{array}{l}\text { Kumar et al. } \\
{[64]}\end{array}$ & Serum & 0.89 & 1.15 & 70 & 0.26 \\
\hline
\end{tabular}

OSF and control groups. The average effect sizes for $\mathrm{Zn}, \mathrm{Cu}$, and $\mathrm{Fe}$ are illustrated by the square symbol in the bottom most row in the respective forest plots. The horizontal line passing the square symbol demonstrates a $95 \%$ confidence interval for the average effect size. Each diamond symbol in the forest plot indicates the effect size for a study. The experiments with a greater number of participants have lower confidence intervals.

3.2. Moderator Analysis. The biomarkers (saliva/serum/ plasma) and proportion of men in the OSF group were used as moderators. The subgroup analysis indicated that none of the moderators had a significant influence on the effect size $(p>0.05)$. Although it is known that a greater proportion of men than women suffer from OSF, the statistically insignificant results for the moderator could be due to the smaller number of investigations that reported the sex of participants.

\section{Discussion}

This is the first meta-analysis to collectively analyze the levels of trace elements of $\mathrm{Zn}, \mathrm{Cu}$, and $\mathrm{Fe}$ in OSF participants as compared to healthy controls, controlling for the 


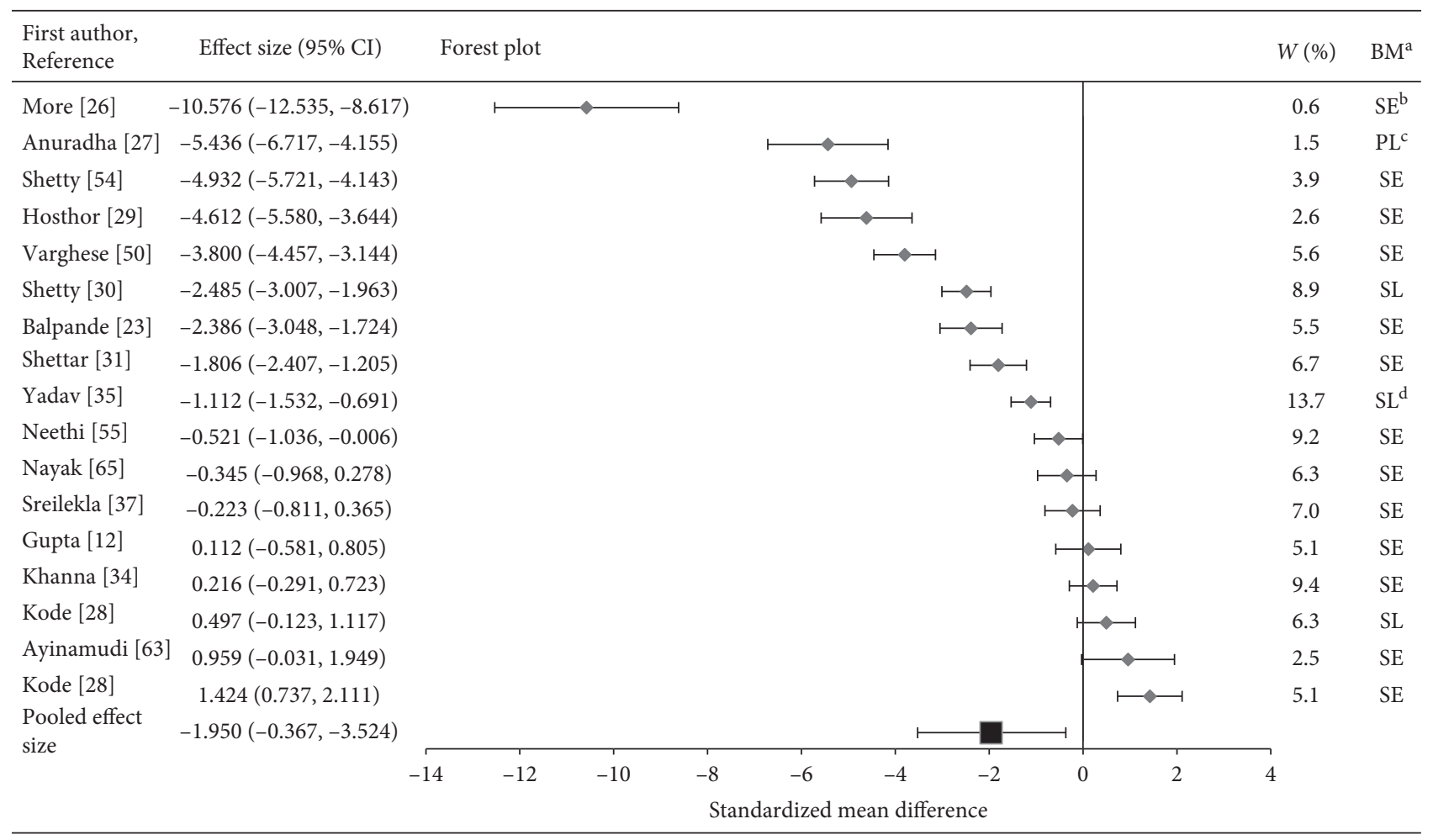

Figure 2: Forest plot of pooled effect size estimates and 95\% confidence intervals representing differences in levels of salivary, serum, or plasma zinc between oral submucous fibrosis patients and healthy controls.

interactions between these micronutrients. This meta-analysis made use of the sophisticated statistical technique of robust variance estimation to handle the dependency between trace elements. The results of this research suggest that the levels of $\mathrm{Zn}$ and $\mathrm{Fe}$ are lower, and $\mathrm{Cu}$ levels are higher, in participants with OSF. The high extent of heterogeneity between the studies, as seen by the high I square value, could be due to the varying type of biological samples (serum, plasma, or saliva) and/or the sex of the participants. The gender and biological samples (serum, plasma, or saliva) used was included as moderator to evaluate for any discrepancies in levels of micronutrients affecting the overall results. Both the biological sample and gender did not affect the difference in the levels of trace elements between OSF and healthy controls. The level of plasma/serum/saliva $\mathrm{Zn}$ in OSF participants has been evaluated in numerous investigations $[4,23,26,27,29-31,35,37,55]$. Only four of these did not report lower Zn levels in OSF patients [12, 28, 34, 63].

An imbalance in the ratio of $\mathrm{Zn}$ to $\mathrm{Cu}$ has been observed in malignant $[70,71]$ as well as inflammatory conditions [72]. Dietary $\mathrm{Zn}$ interferes with $\mathrm{Cu}$ absorption by inducing the synthesis of metallothionein, a protein which sequesters copper, making it unavailable for absorption [73]. Shettar [31] has documented a progressive increase in serum copper levels from Grade I $(126 \mu \mathrm{g} / \mathrm{dl})$ to Grade IV $(146 \mu \mathrm{g} / \mathrm{dl})$ of OSF, with an increase in $\mathrm{Cu} / \mathrm{Zn}$ ratio with advancement of the disease. Fe has been observed to interfere in the absorption of $\mathrm{Cu}$ in the blood [74]. The ratios of $\mathrm{Zn} / \mathrm{Cu}$ and $\mathrm{Cu} / \mathrm{Fe}$ were also calculated from all the studies in order to identify whether a common trend indicating alterations in these ratios exits in OSF patients as compared to healthy participants. A decrease in the ratio of $\mathrm{Zn} / \mathrm{Cu}$ (Table 2) was documented suggesting a decline in $\mathrm{Zn}$, increase in Cu levels, or both in OSF patients as compared to controls. Similarly, an increase in the $\mathrm{Cu} / \mathrm{Fe}$ ratio can be observed (Table 3), suggesting an increase in $\mathrm{Cu}$, decrease in $\mathrm{Fe}$, or both in OSF patients as compared to controls. The pooled differences in $\mathrm{Zn} / \mathrm{Cu}$ ratio and $\mathrm{Cu} / \mathrm{Fe}$ ratios between OSF and healthy participants were -0.3046 and 0.9826 . These numbers indicate that the pooled difference in $\mathrm{Zn} / \mathrm{Cu}$ ratio was negative and $\mathrm{Cu} / \mathrm{Fe}$ was positive between OSF and healthy participants, which may reflect the underlying oxidative stress status. Increase in $\mathrm{Cu}$ can exacerbate the oxidative stress in the body by elevating the free-radical production. Alterations in these ratios indicate a disease status but may also be beneficial in indicating any advancement in the diseases towards malignancy. These results also stress the use of copper chelation therapies, which reduce the levels of $\mathrm{Cu}$ in OSF participants.

Many reasons have been suggested to explain the decreased $\mathrm{Zn}$ levels in OSF participants. This trace mineral is known to be an important antioxidant via several mechanisms. First, it acts as the cofactor $\mathrm{Cu} / \mathrm{Zn}$-superoxide dismutase enzyme $(\mathrm{Cu} / \mathrm{Zn}$-SOD) to serve as the first-line of defense against reactive oxygen species in the cells [75]. Second, it is crucial for the gene expression of the antioxidant protein, metallothionein, which scavenges hydroxyl ions and protects the cells against oxidative damage [76]. Third, zinc competes with the transition metals for binding sites, reducing the availability of those metals for reactions that generate hydroxyl ions [76]. Neutralization of free 


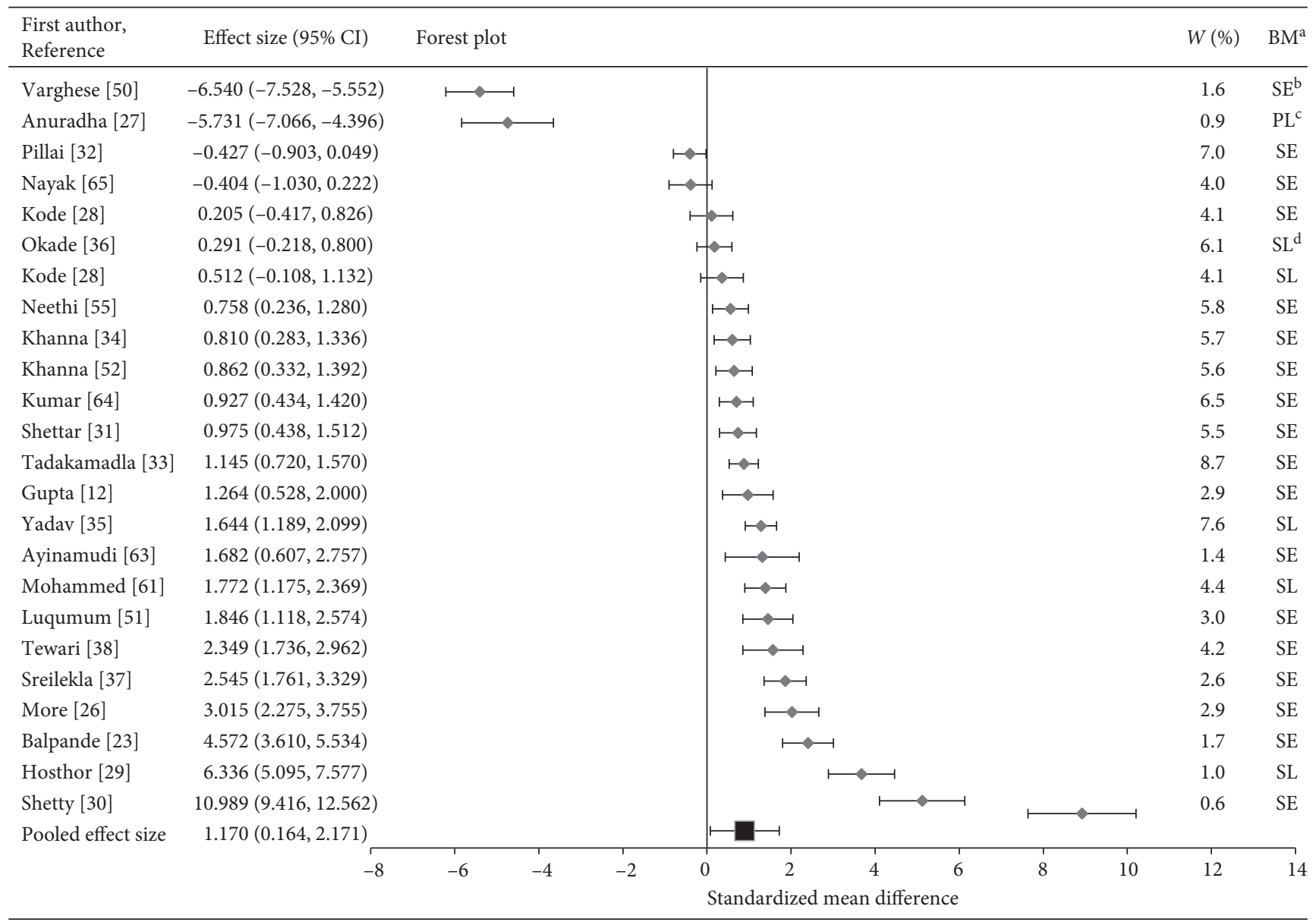

FiguRE 3: Forest plot of pooled effect size estimates and 95\% confidence intervals representing differences in levels of salivary, serum, or plasma copper between oral submucous fibrosis patients and healthy controls.

radicals generated by the areca nut may cause excessive cellular uptake of $\mathrm{Zn}$, thereby resulting in decreased $\mathrm{Zn}$ levels in the patients [15].

$\mathrm{Zn}$ also may play an important role in preventing the development of malignancy. The Zn-dependent protein p-53 gene is involved in the repair of DNA [76]. In addition, the transcription factors of AP-1 and NF- $k \mathrm{~B}$ which regulate apoptosis and defense responses against oxidative stress can undergo alterations with the reduction in cellular levels of zinc [76]. Thus, deficiency of zinc may disrupt the processes of DNA repair, apoptosis, and increase the susceptibility of the cells to oxidative stress [76]. A lack of $\mathrm{Zn}$ also induces overexpression of COX-2 which may promote cell proliferation and inhibit apoptosis, thereby contributing to the malignant transformation of OSF to oral carcinomas [76].

In contrast, relatively fewer studies have documented higher $\mathrm{Zn}$ concentrations in OSF [28,63], as compared to healthy subjects. Although Khanna et al. [34] reported greater $\mathrm{Zn}$ levels in OSF subjects, differences were not statistically significant. The consumption of gutkha (a preparation of betel nut), which has a high $\mathrm{Zn}$ content, could possibly explain the elevated zinc levels in some OSF subjects. Several publications have studied the effect of $\mathrm{Zn}$ supplementation in diseases similar to OSF that are induced by free-radical damage such as type I diabetes [77] and macular degeneration [78].

Copper $(\mathrm{Cu})$ is an integral part of $\mathrm{Cu} / \mathrm{Zn}-\mathrm{SOD}$, an enzyme which also serves as an important antioxidant defense mechanism in the body. The SOD enzyme changes the superoxide ion $\mathrm{O}_{2}{ }^{-}$into either molecular oxygen $\left(\mathrm{O}_{2}\right)$ or hydrogen peroxide $\left(\mathrm{H}_{2} \mathrm{O}_{2}\right)$ by either addition or removal of an electron [18]. In this process, there is either a reduction of the $\mathrm{Cu}^{2+}$ to $\mathrm{Cu}+$ or oxidation from $\mathrm{Cu}+$ to $\mathrm{Cu}^{2+}$ state [18]. Yet, when $\mathrm{Cu}$ is present in high concentrations, it generates reactive oxygen species that induce oxidative damage to the cell $[79,80]$. Several studies have reported elevated Cu levels in the sera of OSF patients $[31,33,63]$, presumably due to chewing areca nut which is rich in $\mathrm{Cu}(302 \mathrm{nmol} / \mathrm{gm})$ [49]. High levels of $\mathrm{Cu}$ in the serum of OSF patients also may be attributed to the inflammatory response to the areca nut, in which the liver releases the copper-carrying ceruloplasmin protein [63]. Finally, decreased catabolism of ceruloplasmin may increase $\mathrm{Cu}$ levels in OSF patients [63]. Though there is not enough evidence on the release of copper from its enzymes in OSF, Winyard et al. observed that ceruloplasmin releases $\mathrm{Cu}$ during the oxidative stress induced by low-intensity UV irradiation [81]. OSF induces a state of oxidative stress, where ceruloplasmin may be releasing increased $\mathrm{Cu}$ in the body. 


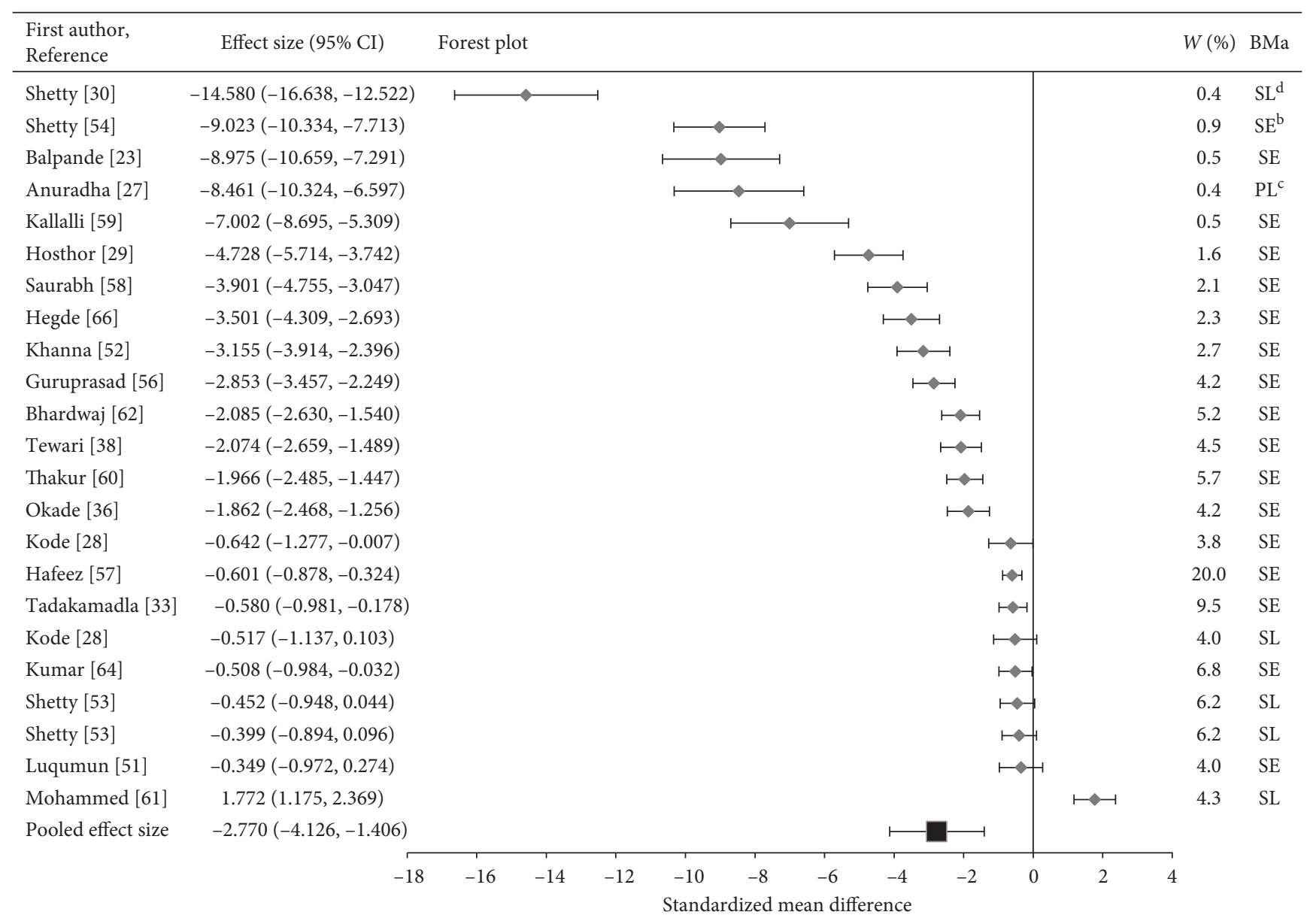

FIGURE 4: Forest plot of pooled effect size estimates and 95\% confidence intervals representing differences in levels of salivary, serum, or plasma iron between oral submucous fibrosis patients and healthy controls.

The chewing of the areca nut releases $\mathrm{Cu}$ which is taken into the oral mucosal keratinocytes through a non-enzymedependent diffusion process, bound to the protein metallothionein [8]. The increased copper upregulates the activity of lysyl oxidase, which increases collagen production. Several studies have investigated the copper levels in fibrotic lesions. Trivedy et al. documented upregulation of collagen synthesis by oral fibroblasts that were incubated with copper chloride as compared to those without copper [46]. Neve et al. documented significantly higher mean copper levels in the erythrocytes, but not in plasma, in cystic fibrosis patients $(3.56 \mu \mathrm{g} / \mathrm{g} \mathrm{Hb} \pm 0.50)$ as compared to healthy age-matched controls $(2.73 \mu \mathrm{g} / \mathrm{g} \mathrm{Hb} \pm 0.30)$ [82]. Also, reduced activity of two copper containing enzymes, cytochrome oxidase and $\mathrm{Zn}-\mathrm{Cu}$ SOD, was documented in the neutrophils and erythrocytes of children suffering from cystic fibrosis [83]. Increased hepatic copper was observed in cirrhotics, with a significant association between the excess copper and liver fibrosis [84]. Although increased iron overload also promotes collagen synthesis, it appears to be more closely related to steatosis than to fibrosis in chronic alcoholics [85]. In contrast, Hughes et al. found no significant difference in levels of serum copper and ceruloplasmin between controls and patients suffering from systemic sclerosis [86]. The effectiveness of copper chelators in treatment of fibrotic lesions also has been established in animal models $[87,88]$. Brewer et al. documented inhibition of fibrosis (independent of inhibition of inflammation) in the bleomycin mouse model of pulmonary fibrosis treated with tetrathiomolybdate, a copper chelator [87]. Finally, Gong et al. observed amelioration in diabetesevoked renal fibrosis in rat cells treated with a copper chelator [88].

The role of excess copper in carcinogenesis also has been the subject of investigations [89-91]. High intracellular levels of copper can generate hydroxyl radicals that cause damage to the DNA and protein molecules. In addition, this may activate angiogenesis factors such as tumor necrosis factor alpha and vascular endothelial growth factor [89]. These angiogenetic factors play an important role in tumor growth and metastasis [89]. The blood level of ceruloplasmin (a Cu-transporting protein) has been observed to be increased from four- to eightfold during OSF malignancy [13]. Ceruloplasmin serves as a source of $\mathrm{Cu}(\mathrm{I})$ ions, which may initiate the process of LDL oxidation and play a role in the malignant transformation of OSF to oral carcinoma [91]. The high copper content can generate reactive oxygen species by Fenton and Haber-Weiss reaction [92]. 
Two publications reported statistically significant lower levels of $\mathrm{Cu}$ in OSF participants $[27,50]$ as compared to healthy controls. Varghese et al. suggested that the decrease in copper levels noted in the study, contrary to prior studies, could be due to the difference in lab methodologies employed and the selection of the patients [50]. This study used atomic absorption spectrophotometry to measure levels of copper, and the patients selected were not on any treatments as opposed to earlier studies that used calorimeter and the patients were on treatment for OSF. However, many later studies [12, 33, 34] that employed atomic absorption spectrophotometry did obtain higher copper levels in OSF patients. Anuradha and Devi also found lower levels of copper in plasma of OSF participants [27]. The sample size was 22, which was lower compared to most of the other studies. The method of $\mathrm{Cu}$ estimation was diethyldithiocarbamate followed by reading the results with a calorimeter. In addition, the patients included in this study had poor dietary patterns and experienced loss of appetite, which could have affected the $\mathrm{Cu}$ levels. Both these investigations were the earliest that compared levels of trace elements in OSF versus healthy participants. Other research studies have documented higher copper levels in oral mucosal tissue [4, 32], saliva [28], but not in the serum as compared to healthy controls. It has been suggested that the alterations in the levels of trace elements are seen predominantly in oral tissues and may not manifest themselves systematically in the serum and plasma [65]. Many of the other later studies, however, did document higher levels of $\mathrm{Cu}$ in the serum of OSF patients $[23,29,30]$. The biomarkers (saliva/serum/plasma) in the OSF group were used as moderators. The subgroup analysis indicated that the biological fluid did not have a significant influence on the effect size ( $p>0.05)$. In other words, the levels of $\mathrm{Zn}, \mathrm{Cu}$, and Fe did not vary significantly because of the biological fluid they were measured from. The statistically insignificant effect of the type of biological fluid used could be due to the smaller number of investigations that measured trace elements in the saliva.

Iron serves many vital functions in the body. It is required for the transport of oxygen from the lungs to the cells in the form of hemoglobin, plays an important role in DNA synthesis and energy metabolism, and is crucial for the development and maintenance of oral mucosa. In investigations that have evaluated the levels of $\mathrm{Fe}$ in OSF $[23,27,30,36,38,52,54,56,60]$, mean serum Fe concentrations in OSF patients were lower than the control groups, and the collagen content was significantly higher.

It has been suggested that diminution in Fe levels in OSF might be due to excessive utilization of $\mathrm{Fe}$ in the hydroxylation of proline and lysine for collagen synthesis [93]. Additionally, the chewing areca nut induces mechanical injury to the oral tissues, which may hamper the ability to ingest a nutritionally adequate diet [94]. Finally, chronic iron deficiency is a risk factor for the development of OSF [94] and anemia has been noted in the advanced stages of OSF [94].

The role of $\mathrm{Fe}$ in carcinogenesis remains controversial, as both excess and deficiency of iron have been linked to increased risk of developing cancer [95]. A chronic deficiency of iron may increase the susceptibility of the oral mucosa to the irritants from the areca nut [25]. Iron deficiency also has been associated with epithelial abnormalities and tumors of the mouth and pharynx [96]. The key features of OSF, chronic inflammation and epithelial dysfunction, have been observed in individuals and lab animals with iron deficiency [95]. Chronic inflammation has been associated with greater risk of cancer in many organs of the body [97]. Additionally, deficiency of iron may increase oxidative stress and DNA damage, conditions that have been linked to carcinogenesis [95]. Again, there is not enough evidence on release of Fe from its enzymes in OSF, but Winrow et al. have suggested that under acidotic conditions of the inflammation, iron is released from ferritin and xanthine oxidoreductase, leading to increase in Fe-catalyzed free radicals [98]. Paul et al. suggested that increase in iron content in the tissues of OSF patients could be because of similar inflammatory condition generated in OSF [45]. However, most of the studies recorded lower Fe in OSF patients; hence, additional research is needed to document the release of Fe from its enzymes in OSF patients. Thakur and Guttikonda [60] found that both hemoglobin and serum ferritin levels were reduced, while total iron binding was increased, in OSF patients compared to healthy controls. Similarly, Rajendran et al. [49] and Anuradha and Devi [27] also documented increased iron binding capacity in OSF versus healthy controls.

Few studies have documented the effect of supplementation of antioxidants and micronutrients therapy in correction of nutritional deficiencies in OSF patients. Thakur et al. found a significant improvement in the mouth opening at the end of 6 weeks in patients who were supplemented with the Mmo3 capsule [99]. Maher et al. documented significant improvement in burning sensation and mouth opening for 117 participants that were supplemented with a combination of vitamins (A, B complex, C, D, and E) and minerals (iron, calcium, copper, zinc, and magnesium) [100]. Jirge et al. observed improvement in the mouth opening by $6.7 \%$ in the OSF participants who received antioxidants (beta carotene: $10 \mathrm{mg}$; zinc sulphate monohydrate: $27.5 \mathrm{mg}$; selenium dioxide: $70 \mathrm{mg}$; manganese: $2 \mathrm{mg}$; copper: $1 \mathrm{mg}$ ) for 15 weeks [101]. Borle and Borle reported healing of vesicles, improvement in burning sensation, and relaxation in stiffness of the buccal mucosa folds in patients who were given Vitamin A, oral ferrous fumarate, and betamethasone for 3 weeks [102]. However, none of these studies reported the levels of micronutrients after intervention. Proteolytic enzymes such as hyaluronidase [103] and chymotrypsin also have been used in management of OSF [104]. However, none of these studies measured the levels of trace elements in OSF patients after intervention or after therapy. Therefore, no concrete data are available on the possible recovery of $\mathrm{Fe}, \mathrm{Cu}$, and $\mathrm{Zn}$ to normal levels after treatment with chelators or other medications. Since the present research is a meta-analysis that statistically summarized the results from others, data could not be derived on the recovery of $\mathrm{Fe}, \mathrm{Cu}$, and $\mathrm{Zn}$. 


\section{Limitations}

A limitation of this research is the relatively small sample size of many of the studies included in this meta-analysis. Also, different measurement techniques and biological specimens (serum, plasma, and saliva) were utilized for assessment of levels of trace elements, resulting in substantial between-study heterogeneity. This heterogeneity is shown by the high $\mathrm{I}^{2}$ value of $97.24 \%$. Although it cannot be determined with certainty that trace element levels are different between OSF and healthy controls, most studies found statistically significant differences in trace element levels of $\mathrm{Zn}, \mathrm{Cu}$, and Fe between OSF patients and healthy controls.

Dietary intake data were not reported in the studies included; thus, the influence of diet is unknown. Yet, it has been observed that restricted mouth opening in OSF participants can predispose one to dietary deficiencies.

It is recognized that serum ferritin and transferrin receptors are the biomarkers of choice for measuring Fe status [105], but the current study was restricted to use of serum/plasma/salivary levels of Fe. However, one parameter of Fe status, hemoglobin, has been reported to be lower in OSF subjects [24, 27, 42-44, 106]. Recently, Thakur et al. [60] found that both hemoglobin and serum ferritin levels were reduced, while total iron binding was increased, in OSF patients compared to healthy controls. Similarly, Rajendran et al. [49] and Anuradha and Devi [27] also documented increased iron-binding capacity in OSF versus healthy controls. Thus, future research should include other biomarkers of iron status.

\section{Conclusions}

This is the first meta-analysis that has investigated the variations in the status of trace elements in the saliva/ plasma/serum of patients suffering from OSF, as compared to healthy individuals by the use of the statistical technique of robust variance estimation. The use of this technique accounted for the dependency between these micronutrients. Also, this method allowed for pooling the studies together to calculate a pooled effect size for $\mathrm{Zn}, \mathrm{Cu}$, and $\mathrm{Fe}$, controlling for the variations in laboratory methods and biological samples used by different investigators. In addition, this research included calculations of the ratios of $\mathrm{Zn} / \mathrm{Cu}$ and $\mathrm{Cu} / \mathrm{Fe}$ from these studies and conducted a metaanalysis to evaluate differences in these ratios between OSF and healthy participants. Levels of $\mathrm{Zn}$ and Fe were lower, and $\mathrm{Cu}$ levels higher, in OSF patients as compared to controls. OSF is a potentially malignant lesion that can cause significant morbidity and mortality. Cessation of areca nut chewing may be the first most important step towards reducing the occurrence and progression of this disease. Previous studies have investigated the effectiveness of micronutrient supplementation in resolving the symptoms of OSF. OSF patients have been supplemented with $\mathrm{Cu}$ in two studies. This is important to consider as this metaanalysis reported higher levels of $\mathrm{Cu}$ in OSMF patients as compared to controls. It is plausible that $\mathrm{Cu}$, in higher concentrations, could aggravate any oxidative damage. Additional research is needed to investigate the potential adverse health effects of copper supplementation in OSF patients.

\section{Data Availability}

The dataset used for this analysis lies with the corresponding author and can be made available on request.

\section{Disclosure}

This meta-analysis has been presented as an abstract at the Experimental Biology Conference in 2017. As a result, it exists as an abstract in the FASEB journal, available at the following link: https://www.fasebj.org/doi/abs/10.1096/ fasebj.31.1_supplement.637.9. However, the complete manuscript has been submitted only to the International Journal of Dentistry.

\section{Conflicts of Interest}

The author declares that there are no conflicts of interest regarding the publication of this article.

\section{Funding}

Bess Heflin Centennial Professorship no. 3086006875.

\section{References}

[1] J. J. Pindborg and S. M. Sirsat, "Oral submucous fibrosis," Oral Surgery, Oral Medicine, Oral Pathology, vol. 22, no. 6, pp. 764-779, 1966.

[2] K. Ranganathan, M. U. Devi, E. Joshua, K. Kirankumar, and T. Saraswathi, "Oral submucous fibrosis: a case-control study in Chennai, South India," Journal of Oral Pathology and Medicine, vol. 33, no. 5, pp. 274-277, 2004.

[3] J. J. Pindborg, F. S. Mehta, P. C. Gupta, and D. K. Daftary, "Prevalence of oral submucous fibrosis among 50,915 Indian villagers," British Journal of Cancer, vol. 22, no. 4, pp. 646654, 1968.

[4] Y. Yang, H. Lee, S. Tung, and T. Shieh, "Epidemiological survey of oral submucous fibrosis and leukoplakia in aborigines of Taiwan," Journal of Oral Pathology and Medicine, vol. 30, no. 4, pp. 213-219, 2001.

[5] P. Murti, R. Bhonsle, J. Pindborg, D. Daftary, P. Gupta, and F. S. Mehta, "Malignant transformation rate in oral submucous fibrosis over a 17-year period," Community Dentistry and Oral Epidemiology, vol. 13, no. 6, pp. 340-341, 1985.

[6] World Health Organization and InternationalAgency for Research on Cancer, Betel-Quid and Areca-Nut Chewing and Some Areca-Nut-Derived Nitrosamines, Vol. 85, International Agency for Research on Cancer, Lyon, France, 2004.

[7] P. Sinor, P. Gupta, P. Murti et al., "A case-control study of oral submucous fibrosis with special reference to the etiologic role of areca nut," Journal of Oral Pathology and Medicine, vol. 19, no. 2, pp. 94-98, 1990.

[8] R. Maher, A. Lee, K. Warnakulasuriya, J. Lewis, and N. Johnson, "Role of areca nut in the causation of oral submucous fibrosis: a case-control study in Pakistan," 
Journal of Oral Pathology and Medicine, vol. 23, no. 2, pp. 65-69, 1994.

[9] P. Murti, R. Bhonsle, P. Gupta, D. Daftary, J. Pindborg, and F. S. Mehta, "Etiology of oral submucous fibrosis with special reference to the role of areca nut chewing," Journal of Oral Pathology and Medicine, vol. 24, no. 4, pp. 145-152, 1995.

[10] R. V. Prabhu, V. Prabhu, L. Chatra, P. Shenai, N. Suvarna, and S. Dandekeri, "Areca nut and its role in oral submucous fibrosis," Journal of Clinical and Experimental Dentistry, vol. 6, no. 5, pp. e569-e575, 2014.

[11] C. Wyk, H. Seedat, and V. Phillips, "Collagen in submucous fibrosis: an electron-microscopic study," Journal of Oral Pathology and Medicine, vol. 19, no. 4, pp. 182-187, 1990.

[12] R. Gupta, K. Rai, D. Hemani, and A. Gupta, "Study of trace elements (copper \& zinc) in oral submucous fibrosis," Indian Journal of Otolaryngology, vol. 39, no. 3, pp. 104-106, 1987.

[13] A. Jayadeep, K. Raveendran Pillai, S. Kannan et al., "Serum levels of copper, zinc, iron and ceruplasmin in oral leukoplakia and squamous cell carcinoma," Journal of Experimental and Clinical Cancer Research, vol. 16, no. 3, pp. 295-300, 1997.

[14] M. Diez, M. Arroyo, F. Cerdan, M. Munoz, M. Martin, and J. Balibrea, "Serum and tissue trace metal levels in lung cancer," Oncology, vol. 46, no. 4, pp. 230-234, 1989.

[15] A. S. Prasad, "Zinc is an antioxidant and anti-inflammatory agent: its role in human health," Frontiers in Nutrition, vol. 1, pp. 14-23, 2014.

[16] A. Uikey, V. Hazarey, and S. Vaidhya, "Estimation of serum antioxidant enzymes superoxide dismutase and glutathione peroxidase in oral submucous fibrosis: a biochemical study," Journal of Oral and Maxillofacial Pathology, vol. 7, no. 2, pp. 44-45, 2003.

[17] M. Angelova, S. Asenova, V. Nedkova, and R. KolevaKolarova, "Copper in the human organism," Trakia Journal of Sciences, vol. 9, no. 1, pp. 88-98, 2011.

[18] J. A. Tainer, E. D. Getzoff, J. S. Richardson, and D. C. Richardson, "Structure and mechanism of copper, zinc superoxide dismutase," Nature, vol. 306, no. 5940, pp. 284-287, 1983.

[19] R. B. Rucker, T. Kosonen, M. S. Clegg et al., "Copper, lysyl oxidase, and extracellular matrix protein cross-linking," American Journal of Clinical Nutrition, vol. 67, no. 5, pp. 996S-1002S, 1998.

[20] C. Trivedy, D. Baldwin, S. Warnakulasuriya, N. Johnson, and T. Peters, "Copper content in Areca catechu (betel nut) products and oral submucous fibrosis," The Lancet, vol. 349, no. 9063, p. 1447, 1997.

[21] C. Trivedy, K. Warnakulasuriya, V. Hazarey, M. Tavassoli, P. Sommer, and N. Johnson, "The upregulation of lysyl oxidase in oral submucous fibrosis and squamous cell carcinoma," Journal of Oral Pathology and Medicine, vol. 28, no. 6, pp. 246-251, 1999.

[22] P. T. Bhattacharya, S. R. Misra, and M. Hussain, "Nutritional aspects of essential trace elements in oral health and disease: an extensive review," Scientifica, vol. 2016, Article ID 5464373, 12 pages, 2016.

[23] A. R. Balpande and R. Sathawane, "Estimation and comparative evaluation of serum iron, copper, zinc and copper/ zinc ratio in oral leukoplakia, submucous fibrosis and squamous cell carcinoma," Journal of Indian Academy of Oral Medicine and Radiology, vol. 22, no. 2, pp. 73-76, 2010.

[24] S. Kapoora, M. Kaurb, C. Dangib et al., "Quantitative analysis of trace elements and haemoglobin as biological markers in patients with oral submucous fibrosis in Central India," Journal of Public Health, vol. 115, pp. 147-149, 2013.

[25] J. Rennie, D. MacDonald, and J. Dagg, "Iron and the oral epithelium: a review," Journal of the Royal Society of Medicine, vol. 77, no. 7, pp. 602-607, 1984.

[26] C. B. More and H. Patel, "Trace elements in potentially oral malignant disorders and oral malignant lesion-a biochemical study," International Journal of Oral and Maxillofacial Diseases, vol. 1, no. 2, pp. 1-7, 2016.

[27] C. D. Anuradha and C. S. S. Devi, "Studies on the hematological profile and trace elements in oral submucous fibrosis," Journal of Clinical Biochemistry and Nutrition, vol. 19, no. 1, pp. 9-17, 1995.

[28] M. A. Kode and F. R. Karjodkar, "Estimation of the serum and the salivary trace elements in OSMF patients," Journal of Clinical and Diagnostic Research, vol. 7, no. 6, pp. 1215-1218, 2013.

[29] S. S. Hosthor, P. Mahesh, S. A. Priya, P. Sharada, M. Jyotsna, and S. Chitra, "Quantitative analysis of serum levels of trace elements in patients with oral submucous fibrosis and oral squamous cell carcinoma: a randomized cross-sectional study," Journal of Oral and Maxillofacial Pathology, vol. 18, no. 1, pp. 46-51, 2014.

[30] S. R. Shetty, S. Babu, S. Kumari, P. Shetty, S. Hegde, and A. Karikal, "Status of trace elements in saliva of oral precancer and oral cancer patients," Journal of Cancer Research and Therapeutics, vol. 11, no. 1, pp. 146-149, 2015.

[31] S. S. Shettar, "Estimation of serum copper and zinc levels in patients with oral submucous fibrosis," Journal of Indian Academy of Oral Medicine and Radiology, vol. 22, no. 4, pp. 193-196, 2010.

[32] K. Pillai and K. Burde, "Increased copper level in oral mucosal tissue of patients with submucous fibrosis and who chew areca nut products," West Indian Medical Journal, vol. 54, no. 4, pp. 270-271, 2005.

[33] J. Tadakamadla, S. Kumar, and G. Mamatha, "Evaluation of serum copper and iron levels among oral submucous fibrosis patients," Medicina Oral, Patologia Oral Y Cirugia Bucal, vol. 16, no. 7, pp. e870-e873, 2011.

[34] S. Khanna, A. Udas, G. K. Kumar, S. Suvarna, and F. Karjodkar, "Trace elements (copper, zinc, selenium and molybdenum) as markers in oral sub mucous fibrosis and oral squamous cell carcinoma," Journal of Trace Elements in Medicine and Biology, vol. 27, no. 4, pp. 307-311, 2013.

[35] A. Yadav, L. Kumar, N. Misra, U. Deepak, and G. S. Kumar, "Estimation of serum zinc, copper, and iron in the patients of oral submucous fibrosis," National Journal of Maxillofacial Surgery, vol. 6, no. 2, pp. 190-193, 2015.

[36] A. R. Okade, K. S. Hallikeri, and D. J. Trivedi, "Salivary estimation of copper, iron, zinc and manganese in oral submucous fibrosis patients: a case-control study," Clinical Cancer Investigation Journal, vol. 4, no. 3, pp. 302-3016, 2015.

[37] M. Srileka, "Copper and zinc level in oral submucosal fibrosis (OSMF) patients," International Journal of Pharmacological Sciences, vol. 7, pp. 573-574, 2015.

[38] R. Tiwari, C. M. David, D. R. Mahesh, U. Sambargi, K. J. Rashmi, and P. Benakanal, "Assessment of serum copper, iron and immune complexes in potentially malignant disorders and oral cancer," Brazilian Oral Research, vol. 30, no. 1, pp. E101-E109, 2016.

[39] N. Scammacca, G. Roberts, and K. K. Stuebing, "Metaanalysis with complex research designs: dealing with dependence from multiple measures and multiple group 
comparisons," Review of Educational Research, vol. 84, no. 3, pp. 328-364, 2014.

[40] R. K. Rupapara, D. A. Solanki, and J. Chawda, "Serum copper level in oral submucous fibrosis," International Journal of Research in Medical Sciences, vol. 5, no. 1, pp. 79-81, 2016.

[41] D. Dey, S. S. Thakkannavar, M. Kumar, S. Singh, S. Kona, and S. Salaria, "Evaluation of salivary copper and zinc levels in oral submucous fibrosis patients," International Journal of Health and Allied sciences, vol. 2, no. 2, pp. 35-37, 2016

[42] D. Pathak, M. D. Jani, and M. Machhi, "Evaluation of haemoglobin and iron levels in serum of patients with oral sub mucous fibrosis: a clinical study," National Journal of Integrated Research in Medicine, vol. 5, no. 5, pp. 30-34, 2014.

[43] A. Lamlakar and R. Parashram, "Oral submucous fibrosis and iron deficiency anemia: a clinical study," Journal of Contemporary Medicine and Dentistry, vol. 45, pp. 9-12, 2016.

[44] P. S. Joshi, B. P. Hongal, N. S. Agnihotri, and R. S. Kempwade, "A retrospective study on qualitative assessment of copper content in oral leukoplakia, submucous fibrosis, and squamous cell carcinoma with rhodamine stain," Journal of Interdisciplinary Histopathology, vol. 3, no. 3, pp. 105-109, 2015.

[45] R. R. Paul, J. Chatterjee, A. K. Das, M. L. Cervera, M. de la Guardia, and K. Chaudhuri, "Altered elemental profile as indicator of homeostatic imbalance in pathogenesis of oral submucous fibrosis," Biological Trace Element Research, vol. 87, no. 1-3, pp. 45-49, 2002.

[46] C. Trivedy, K. Warnakulasuriya, T. Peters, R. Senkus, V. Hazarey, and N. Johnson, "Raised tissue copper levels in oral submucous fibrosis," Journal of Oral Pathology and Medicine, vol. 29, no. 6, pp. 241-248, 2000.

[47] A. K. Singh, B. Shivakumar, P. Sanjaya, N. N. Singh, and A. Sahu, "Assessment of tissue copper level in oral submucous fibrosis patients," Journal of Cranio-Maxillary Diseases, vol. 4, no. 1, pp. 33-37, 2015.

[48] IBM Corp., IBM Spss Statistics for Windows, Version 22.0, IBM Corp., Armonk, NY, USA, 2013.

[49] R. Rajendran, D. M. Vasudevan, and T. Vijayakumar, "Serum levels of iron and proteins in oral submucous fibrosis (OSMF)," Annals of Dentistry, vol. 49, no. 2, pp. 23-25, 1990.

[50] I. Varghese, C. Sugathan, G. Balasubramoniyan, and T. Vijayakumar, "Serum copper and zinc levels in premalignant and malignant lesions of the oral cavity," Oncology, vol. 44, no. 4, pp. 224-227, 1987.

[51] M. Luquman, V. Dinesh, and M. Vidya, "The role of serum copper and iron in oral submucous fibrosis," Journal of Indian Academy of Oral Medicine and Radiology, vol. 16, no. 1, pp. 30-32, 2004.

[52] S. S. Khanna and F. R. Karjodkar, "Circulating immune complexes and trace elements (copper, iron and selenium) as markers in oral precancer and cancer: a randomised, controlled clinical trial," Head and Face Medicine, vol. 2, no. 1, pp. 33-42, 2006.

[53] S. R. Shetty, S. Babu, S. Kumari, P. Shetty, R. Vijay, and A. Karikal, "Evaluation of micronutrient status in serum and saliva of oral submucous fibrosis patients: a clinicopathological study," Indian Journal of Medical and Paediatric Oncology, vol. 33, no. 4, pp. 224-226, 2012.

[54] S. R. Shetty, S. Babu, S. Kumari, P. Shetty, S. Hegde, and A. Karikal, "Role of serum trace elements in oral precancer and oral cancer-a biochemical study," Journal of Cancer Research and Treatment, vol. 1, no. 1, pp. 1-3, 2013.
[55] H. Neethi, S. Patil, and R. S. Rao, "Estimation of serum copper and zinc levels in oral submucous fibrosis: an atomic absorption spectroscopic study," Journal of Contemporary Dental Practice, vol. 14, no. 5, pp. 801-805, 2013.

[56] R. Guruprasad, P. P. Nair, M. Singh, M. Singh, M. Singh, and A. Jain, "Serum vitamin c and iron levels in oral submucous fibrosis," Indian Journal of Dentistry, vol. 5, pp. 21-25, 2014.

[57] N. Hafeez, S. M. Haider, and A. Rizwan, "Estimation of serum iron in oral submucous fibrosis patients and its comparison with healthy controls," Pakistan Journal of Otolaryngology, vol. 43, pp. 43-46, 2015.

[58] S. Saurabh, M. Sunil, R. Kumar, A. Mishra, O. Singh Birring, and L. Khan, "Estimation of serum iron and protein levels in oral submucous fibrosis: a clinical research," Journal of Medicine, Radiology, Pathology and Surgery, vol. 1, pp. 3-6, 2015.

[59] B. N. Kallalli, P. K. Gujjar, K. Rawson, S. Bhalerao, T. Pereira, and J. Zingade, "Analysis of iron levels in the mucosal tissue and serum of oral submucous fibrosis patients," Journal of Indian Academy of Oral Medicine and Radiology, vol. 28, no. 2, pp. 119123, 2016.

[60] M. Thakur and V. R. Guttikonda, "Estimation of hemoglobin, serum iron, total iron-binding capacity and serum ferritin levels in oral submucous fibrosis: a clinicopathological study," Journal of Oral and Maxillofacial Pathology, vol. 21, no. 1, pp. 30-35, 2017.

[61] F. Mohammed, V. Manohar, M. Jose et al., "Estimation of copper in saliva and areca nut products and its correlation with histological grades of oral submucous fibrosis," Journal of Oral Pathology and Medicine, vol. 44, no. 3, pp. 208-213, 2016.

[62] D. Bhardwaj, A. D. Dinkar, S. K. Satoskar, and S. R. Desai, "Serum iron and haemoglobin estimation in oral submucous fibrosis and iron deficiency anaemia: a diagnostic approach," Journal of Clinical and Diagnostic Research, vol. 10, no. 12, pp. 54-58, 2016.

[63] B. K. Ayinampudi and M. Narsimhan, "Salivary copper and zinc levels in oral pre-malignant and malignant lesions," Journal of Oral and Maxillofacial Pathology, vol. 16, no. 2, pp. 178-182, 2012.

[64] H. Kumar, P. Kumar, S. Jain, and H. Suryawanshi, "Analysis of serum copper and iron levels in oral submucous fibrosis patients: a case-control study," Indian Journal of Dental Sciences, vol. 8, no. 3, pp. 145-149, 2016.

[65] A. G. Nayak, L. Chatra, and P. Shenai, "Analysis of copper and zinc levels in the mucosal tissue and serum of oral submucous fibrosis patients," World Journal of Dentistry, vol. 1, no. 2, pp. 75-78, 2010.

[66] K. Hegde, H. Gharote, P. Nair, K. Agarwal, N. Saawarn, and D.K. Rajaram, "Iron deficiency in oral submucous fibrosis: accelerator or a promoter?," International Journal of Oral and Maxillofacial Pathology, vol. 3, no. 1, pp. 2-7, 2012.

[67] G. Cumming, Understanding the New Statistics: Effect Sizes, Confidence Intervals, and Meta-Analysis, Routledge, Abingdon, UK, 2013.

[68] H. Cooper, L. V. Hedges, and J. C. Valentine, The Handbook of Research Synthesis and Meta-Analysis, Russell Sage Foundation, New York, NY, USA, 2009.

[69] E. Tipton, "Small sample adjustments for robust variance estimation with meta-regression," Psychological Methods, vol. 20, no. 3, pp. 375-393, 2015.

[70] S. Gupta, S. Singh, and V. Shukla, "Copper, zinc, and Cu/Zn ratio in carcinoma of the gallbladder," Journal of Surgical Oncology, vol. 91, no. 3, pp. 204-208, 2005. 
[71] S. K. Gupta, V. K. Shukla, M. P. Vaidya, S. K. Roy, and S. Gupta, "Serum trace elements and $\mathrm{Cu} / \mathrm{Zn}$ ratio in breast cancer patients," Journal of Surgical Oncology, vol. 46, no. 3, pp. 178-181, 1991.

[72] B. M. Reza, K. Soheila, A. Reza, H. Shaheen, K. A. Ali, and V. A. Akbar, "Evaluation of copper, zinc and copper/zinc ratio in the serum of pulmonary tuberculosis children," Pediatric Oncall Journal, vol. 4, no. 11, pp. 10-15, 2011.

[73] P. Fischer, A. Giroux, and M. L'abbe, "The effect of dietary zinc on intestinal copper absorption," American Journal of Clinical Nutrition, vol. 34, no. 9, pp. 1670-1675, 1981.

[74] S. Yu, R. B. Beems, J. A. Joles, G. A. Kaysen, and A. C. Beynen, "Iron and copper metabolism in analbuminaemic rats fed a high-iron diet," Comparative Biochemistry and Physiology Part A: Physiology, vol. 110, no. 2, pp. 131138, 1995.

[75] L. O. Klotz, K. D. Kroncke, D. P. Buchczyk, and H. Sies, "Role of copper, zinc, selenium and tellurium in the cellular defense against oxidative and nitrosative stress," Journal of Nutrition, vol. 133, no. 5, pp. 1448S-1451S, 2004.

[76] E. Ho, "Zinc deficiency, DNA damage and cancer risk," Journal of Nutritional Biochemistry, vol. 15, no. 10, pp. 572-578, 2004.

[77] E. Ho, N. Quan, Y. Tsai, W. Lai, and T. M. Bray, "Dietary zinc supplementation inhibits $\mathrm{NF \kappa B}$ activation and protects against chemically induced diabetes in CD1 mice," Experimental Biology and Medicine, vol. 226, no. 2, pp. 103-111, 2001.

[78] R. A. Mittra, "New treatments for age-related macular degeneration," Minnesota Medicine, vol. 86, no. 4, pp. 40-46, 2003.

[79] T. Theophanides and J. Anastassopoulou, "Copper and carcinogenesis," Critical reviews in Oncology, vol. 42, no. 1, pp. 57-64, 2002.

[80] L. M. Gaetke and C. K. Chow, "Copper toxicity, oxidative stress, and antioxidant nutrients," Toxicology, vol. 189, no. 1-2, pp. 147-163, 2003.

[81] P. G. Winyard, R. C. Hider, S. Brailsford, A. F. Drake, J. Lunec, and D.R. Blake, "Effects of oxidative stress on some physiochemical properties of caeruloplasmin," Biochemical Journal, vol. 258, no. 2, pp. 435-445, 1989.

[82] J. Neve, R. Geffel, M. Hanocq, and L. Molle, "Plasma and erythrocyte zinc, copper and selenium in cystic fibrosis," Acta Paediatrica, vol. 72, no. 3, pp. 437-440, 1983.

[83] S. S. Percival, E. Bowser, and M. Wagner, "Reduced copper enzyme activities in blood cells of children with cystic fibrosis," American Journal of Clinical Nutrition, vol. 62, no. 3, pp. 633-638, 1995.

[84] F. Rodriguez-Moreno, E. González-Reimers, F. SantolariaFernandez et al., "Zinc, copper, manganese, and iron in chronic alcoholic liver disease," Alcohol, vol. 14, no. 1, pp. 39-44, 1997.

[85] R. Chapman, M. Morgan, M. Laulicht, A. Hoffbrand, and S. Sherlock, "Hepatic iron stores and markers of iron overload in alcoholics and patients with idiopathic hemochromatosis," Digestive Diseases and Science, vol. 27, no. 10, pp. 909-916, 1982.

[86] M. Hughes, G. J. Cooper, J. Wilkinson, P. New, J. M. Guy, and A. L. Herrick, "Abnormalities of selenium but not of copper homeostasis may drive tissue fibrosis in patients with systemic sclerosis," Rheumatology, vol. 54, no. 4, pp. 747-748, 2015.

[87] G. J. Brewer, M. R. Ullenbruch, R. Dick, L. Olivarez, and S. H. Phan, "Tetrathiomolybdate therapy protects against bleomycin-induced pulmonary fibrosis in mice," Journal of Lab and Clinical Medicine, vol. 141, no. 3, pp. 210-216, 2003.

[88] D. Gong, J. Lu, X. Chen et al., "A copper (II)-selective chelator ameliorates diabetes-evoked renal fibrosis and albuminuria, and suppresses pathogenic TGF- $\beta$ activation in the kidneys of rats used as a model of diabetes," Diabetologia, vol. 51, no. 9, pp. 1741-1751, 2008.

[89] A. Nasulewicz, A. Mazur, and A. Opolski, "Role of copper in tumour angiogenesis-clinical implications," Journal of Trace Elements in Medicine and Biology, vol. 18, no. 1, pp. 1-8, 2004.

[90] N. H. Al-Rawi and N. Talabani, "Quantitative analysis of trace elements in saliva of oral cancer patients from Iraq," Journal of College of Dentistry, vol. 17, pp. 32-35, 2005.

[91] C. K. Mukhopadhyay, B. Mazumder, P. F. Lindley, and P. L. Fox, "Identification of the prooxidant site of human ceruloplasmin: a model for oxidative damage by copper bound to protein surfaces," Proceedings of National Academy of Sciences USA, vol. 94, no. 21, pp. 11546-11551, 1997.

[92] H. C. Sutton and C. C. Winterbourn, "On the participation of higher oxidation states of iron and copper in Fenton reactions," Free Radical Biology and Medicine, vol. 6, no. 1, pp. 53-60, 1989.

[93] Y. Cho, "Effect of ascorbic acid, silicon and iron on collagen synthesis in the human dermal fibroblast cell (HS27)," FASEB Journal, vol. 22, no. 2, p. 672, 2008.

[94] H. Mohammad, N. I. Hadi, S. Younus, F. Ahmed, and N. Younus, "Potentially significant biomarkers in oral submucous fibrosis," Pakistan Journal of Medicine and Dentistry, vol. 4, no. 2, pp. 51-55, 2015.

[95] D. Prá, S. I. Rech Franke, J. A. Pêgas Henriques, and M. Fenech, "A possible link between iron deficiency and gastrointestinal carcinogenesis," Nutrition and Cancer, vol. 61, no. 4, pp. 415-426, 2009.

[96] L. Wertheimer-Hatch, G. F. Hatch, G. B. Davis, D. K. Blanchard, R. S. Foster, and J. E. Skandalakis, "Tumors of the oral cavity and pharynx," World Journal of Surgery, vol. 24, no. 4, pp. 395-400, 2000.

[97] P. C. Dedon and S. R. Tannenbaum, "Reactive nitrogen species in the chemical biology of inflammation," Archives of Biochemistry and Biophysics, vol. 423, no. 1, pp. 12-22, 2004.

[98] V. Winrow, P. Winyard, C. Morris, and D. Blake, "Free radicals in inflammation: second messengers and mediators of tissue destruction," British Medical Bulletin, vol. 49, no. 3, pp. 506-522, 1993.

[99] N. Thakur, "Effectiveness of micronutrients and physiotherapy in the management of oral submucous fibrosis," International Journal of Contemporary Dentistry, vol. 2, no. 1, pp. 101-105, 2011.

[100] R. Maher, P. Aga, N. W. Johnson, R. Sankaranarayanan, and S. Warnakulasuriya, "Evaluation of multiple micronutrient supplementation in the management of oral submucous fibrosis in Karachi, Pakistan," Nutrition and Cancer, vol. 27, no. 1, pp. 41-47, 1997.

[101] V. Jirge, M. Shashikanth, I. Ali, and N. Anshumalee, "Levamisole and antioxidants in the management of oral submucous fibrosis: a comparative study," Journal of Indian Academy of Oral Medicine and Radiology, vol. 20, no. 4, p. 135, 2008.

[102] R. M. Borle and S. R. Borle, "Management of oral submucous fibrosis: a conservative approach," Journal of Oral and Maxillofacial Surgery, vol. 49, no. 8, pp. 788-791, 1991.

[103] L. James, A. Shetty, D. Rishi, and M. Abraham, "Management of oral submucous fibrosis with injection of hyaluronidase and dexamethasone in grade III oral submucous 
fibrosis: a retrospective study," Journal of International Oral Health, vol. 7, no. 8, pp. 82-85, 2015.

[104] D. Gupta and S. Sharma, "Oral submucous fibrosis-a new treatment regimen," Journal of Oral and Maxillofacial Surgery, vol. 46, no. 10, pp. 830-833, 1988.

[105] World Health Organization, Serum Ferritin Concentrations for the Assessment of Iron Status and Iron Deficiency in Populations, Vitamin and Mineral Nutrition Information System, Geneva, Switzerland, 2011.

[106] C. Balakrishnan and N. Aswath, "Estimation of serum, salivary immunoglobulin G, immunoglobulin A levels and total protein, hemoglobin in smokeless tobacco chewers and oral submucous fibrosis patients," Contemporary Clinical Dentistry, vol. 6, no. 6, pp. S157-S162, 2015. 


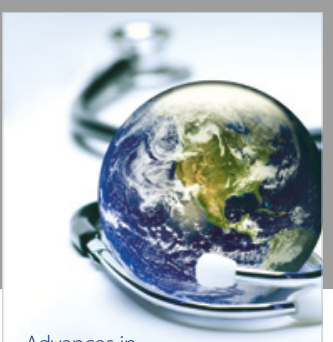

Advances in
Public Health

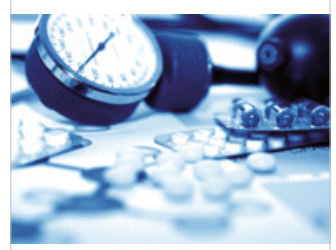

Case Reports in

Medicine

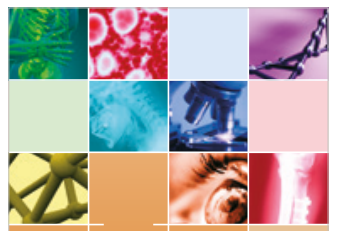

niernational Journal of

Biomaterials
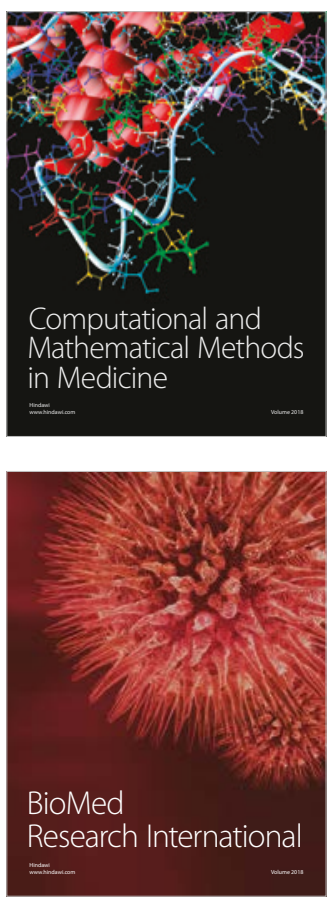

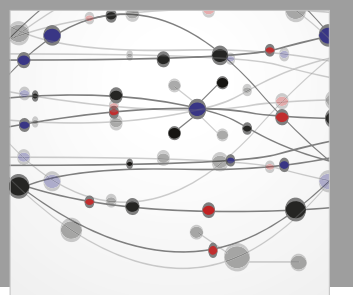

The Scientific World Journal Dentistry

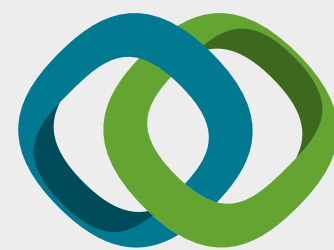

Hindawi

Submit your manuscripts at

www.hindawi.com
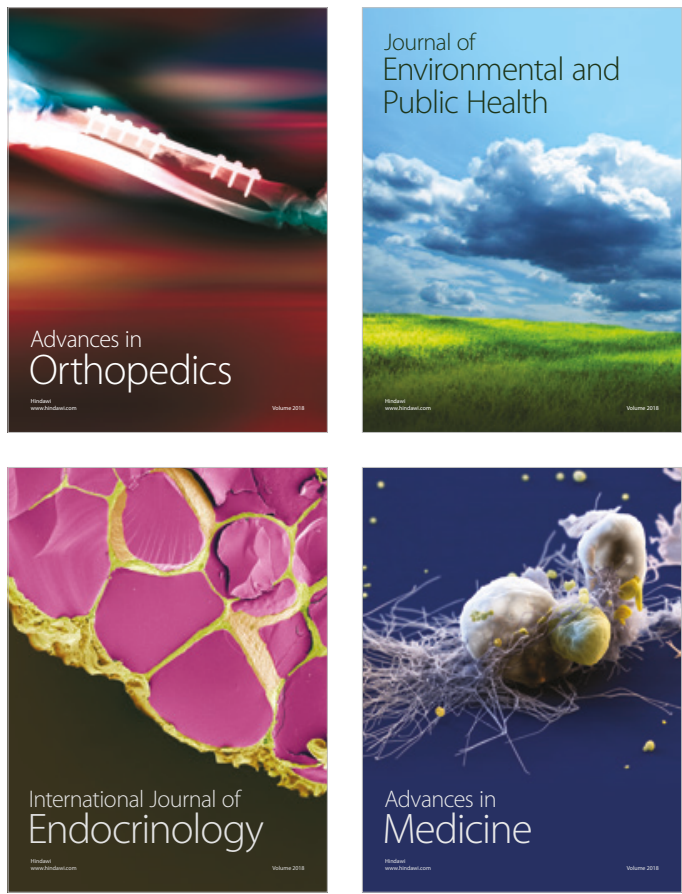
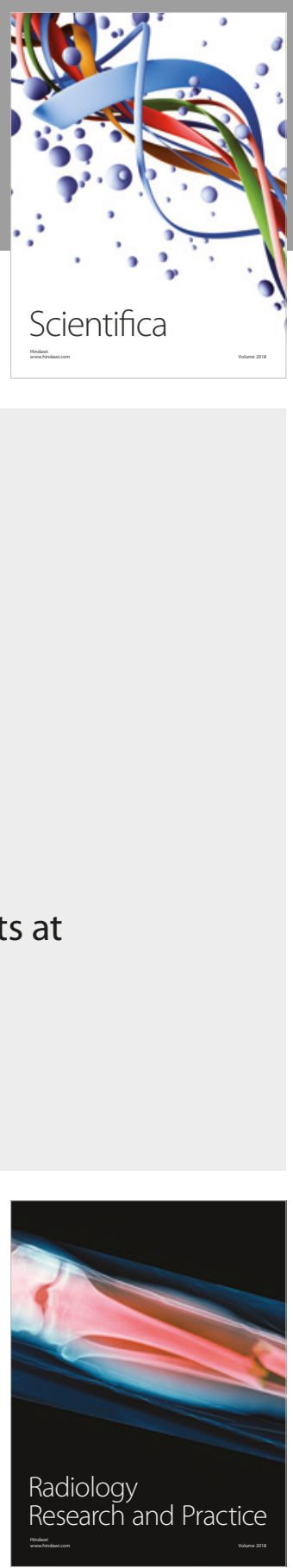

Scientifica

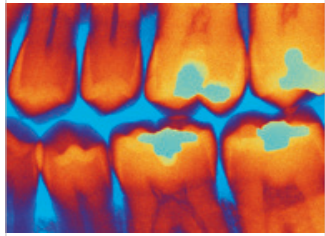

Case Reports in

Dentistry
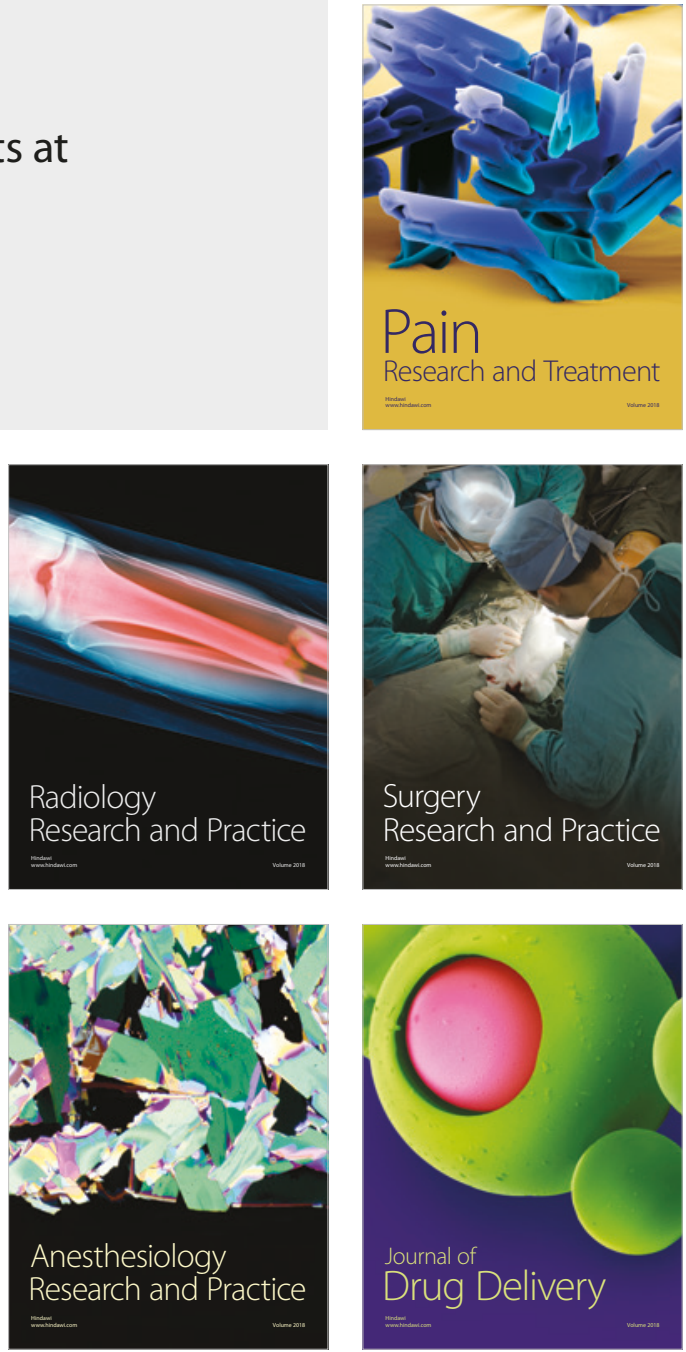